\title{
First record of the invasive Nile Tilapia, Oreochromis niloticus (Linnaeus, 1758) (Perciformes, Cichlidae), on Bawean Island, Indonesia
}

\author{
Veryl Hasan ${ }^{1}$, Muhammad B. Tamam² \\ 1 Airlangga University, Faculty of Fisheries and Marine, Departement of Fish Health and Manajemen Aquaculture, Surabaya 60115, East Java, \\ Indonesia. 2 Generasi Biologi Indonesia, Zoology Division, Gresik 61171, East Java, Indonesia. \\ Corresponding author: Veryl Hasan, verylbp@gmail.com
}

\begin{abstract}
In 2018 we captured specimens of Oreachromis niloticus (Linnaeus, 1758) from Danau Kastoba, a crater lake on Bawean (Indonesia), a small, isolated island in the Java Sea. Additional individuals were later photographed. These records are among first of this species from an isolated island, in the Java Sea. A description of meristic and morphometric features of a specimen are provided.
\end{abstract}

Key words

Cichlid, freshwater fishes, isolated island, Java Sea.

Academic editor: Gabriela Echevarría | Received 15 November 2018 | Accepted 7 February 2019 | Published 15 February 2019

Citation: Hasan V, Tamam MB (2019) First record of the invasive Nile Tilapia, Oreochromis niloticus (Linnaeus, 1758) (Perciformes, Cichlidae), on Bawean Island, Indonesia. Check List 15 (1): 225-227. https://doi.org/10.15560/15.1.225

\section{Introduction}

Oreochromis niloticus Linnaeus, 1758 is a tilapia native to the Nile (Africa) and now introduced to many countries worldwide for aquaculture (Ishikawa et al. 2012). Oreochromis niloticus exhibits fast growth (Qiang et al. 2014) and tolerance to new habitats (Kulac et al. 2014, Abdel-Tawwab 2015). Because of these attributes, $O$. niloticus has the potential to become an invasive species and compete with other fish species for resources (Gu et al. 2015).

In Indonesia, O. niloticus is generally spread in mainland waters where aquaculture activities have been underway for some time (Basuki and Sri 2014). Bawean, a small, isolated island in the Java Sea, is a fisheries center, but there is no record of culturing tilapia there. The existence of $O$. niloticus on Bawean constitutes a new record.

\section{Methods}

Specimens of $O$. niloticus were captured with gill net on 20-21 October 2018. The specimens were preserved in 96\% alcohol solution and deposited at the Hydrobiology Laboratory, Brawijaya University, Malang, Indonesa (Hydro/On/XII/2019). Diagnostic meristic and morphometrics of the specimens were analyzed following Tortonese (1986). Additional specimens of O. niloticus were photographed at the same location on 21 January, 2019.

\section{Results}

New records. (Figs 1, 2). Indonesia: Java Sea: Bawean: Danau Kastoba $\left(05^{\circ} 46^{\prime} 17.1^{\prime \prime}\right.$ S, 112 $40^{\prime} 18.8^{\prime \prime}$ E), 20-21 Oct. 2018, coll. by M.B. Tamam (4 spec., Hydro/On/ $\mathrm{XII} / 2019$, total length 5-14 cm). Same location, 21 Jan. 2019, obs. by V. Hasan (16 spec., photographed). 


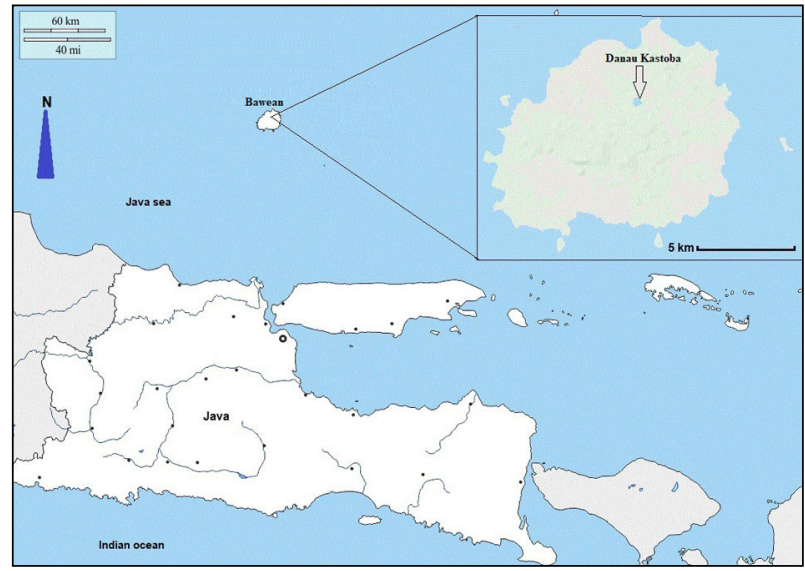

Figure 1. Location of Danau Kastoba on the island of Bawean in the Java Sea.

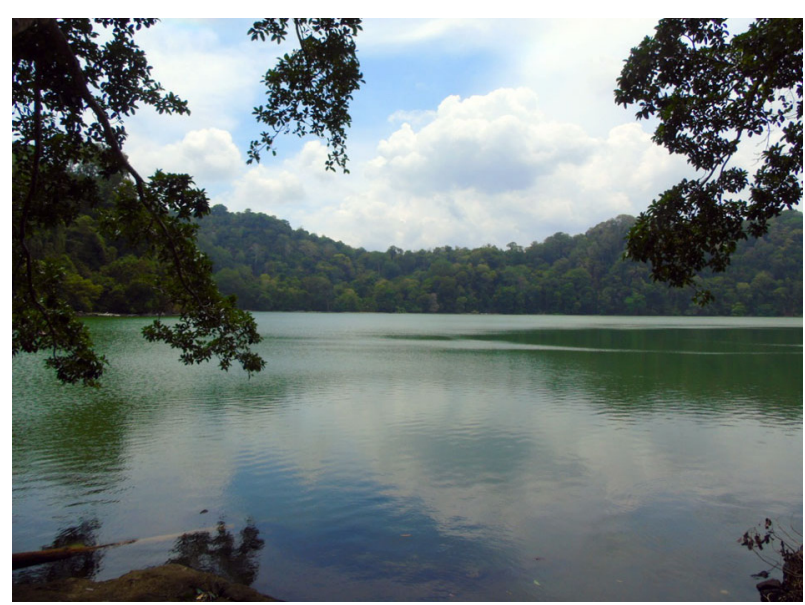

Figure 2. Danau Kastoba location where O. niloticus found in Bawean Island (photograph by M.B. Tamam)

Identification. Meristic and Morphometric characters of $O$. niloticus are given in Table 1. Other specific morphological characters are as follows: scales cycloid; gill rakers short; 3 rows of scales on cheek; maxilla and lower jaw equal; teeth widen; pectoral fin pointed; dorsal, pectoral and anal fins blunt; caudal scaly. Coloration: anal fin faintly barred; caudal and soft dorsal fin sharply barred; about 9 narrow dark bars on sides body; dark blotch at corner of operculum.

Table 1. Meristic and morphometric of Oreochromis niloticus from the Danau Kastoba, Bawean Island ( $n=4$ specimens).

\begin{tabular}{ll}
\hline Character & Meristic \\
\hline Dorsal fin & $\mathrm{XV}+10$ \\
Pectoral fin & 11 \\
Anal fin & $\mathrm{VIII}+10$ \\
Pelvic fin & $\mathrm{I}+5$ \\
Lateral line scales & 30 \\
\hline Character & Morphometric $\mathbf{( c m )}$ \\
\hline Total length & 11.6 \\
Standard length & 9.7 \\
Head length & 3.1 \\
Body depth & 7.3 \\
Eye diameter & 0.8 \\
Snout length & 0.7 \\
\hline
\end{tabular}

\section{Discussion}

Oreochromis niloticus has been introduced to more than 90 countries around the world for both fresh and brackish water aquaculture (Fitzsimmons 2001). This species is one of the top 10 introduced species of animals in the world (Picker and Griffiths 2011).

Indonesia is the second largest producer of $O$. niloticus in the world after China (FAO 2017). Due to intensive aquaculture, $O$. niloticus now occurs in all fresh and brackish waters of mainland Indonesia. Its presence on the island of Bawean, in the middle of Java Sea and 153 $\mathrm{km}$ from the nearest maindland (Fig. 3), is new record.

We speculate that $O$. niloticus was released into Danau Kastoba on Bawean by local people. The purpose is not clear. As the island does not have an aquaculture industry, further investigation is warranted to determine the sourch of O. niloticus on Bawean Island. The control and prevention of further introductions is needed so that $O$. niloticus on does not disturb the natural ecosystem (Speziale et al. 2012).

\section{Acknowledgements}

We thank the Ministry of Finance of the Indonesian Education Fund Management Institute (LPDP) as the Scholarship Program sponsor and or funding our work no. 20160221035555

\section{Authors' Contributions}

VH collected the data and wrote the text, MBT facilitated with field work. All authors corrected, revised and discussed the data.

\section{References}

Abdel-Tawwab M (2005) The effect of artificial vegetation density on growth and growth related parameters of Nile Tilapia, Oreochromis niloticus (L.) fry. Turkish Journal of Fisheries and Aquatic Sciences 5: 63-68.

Basuki F, Sri R (2014) Analysis on the survival rate and growth of Larasati Tilapia (Oreochromis niloticus) F5 seed in saline media. Procedia Environmental Sciences 23: 142-147. https://doi. org/10.1016/j.proenv.2015.01.022

Fitzsimmons K (2001) Environmental and conservation issues in tilapia aquaculture. In: Subasinghe R, Singh T (Eds) Tilapia: Production, Marketing, and Technological Developments. FAO Infofish, Kuala Lumpur, Malaysia, 128-131.

FAO (2017) Global aquaculture production. Food and Agriculture Organization of the United Nations, Rome. http:/www.fao.org/ fishery/statistics/global-production/en. Accessed on: 2018-11-15.

Gu DA, Guang MA, Yun JZ, Meng X, Du L, Ying YL, Hui W, Xi D.M, Jian RL, Yin CH (2015) The impacts of invasive Nile Tilapia (Oreochromis niloticus) on the fisheries in the main rivers of Guangdong Province, China. Biochemical Systematics and Ecology 59: 1-7. https://doi.org/10.1016/j.bse.2015.01.004

Ishikawa T, Tamaki S, Katsunori T (2012) Life history of an invasive and unexploited population of Nile Tilapia (Oreochromis niloticus) and geographical variation across its native and non-native 


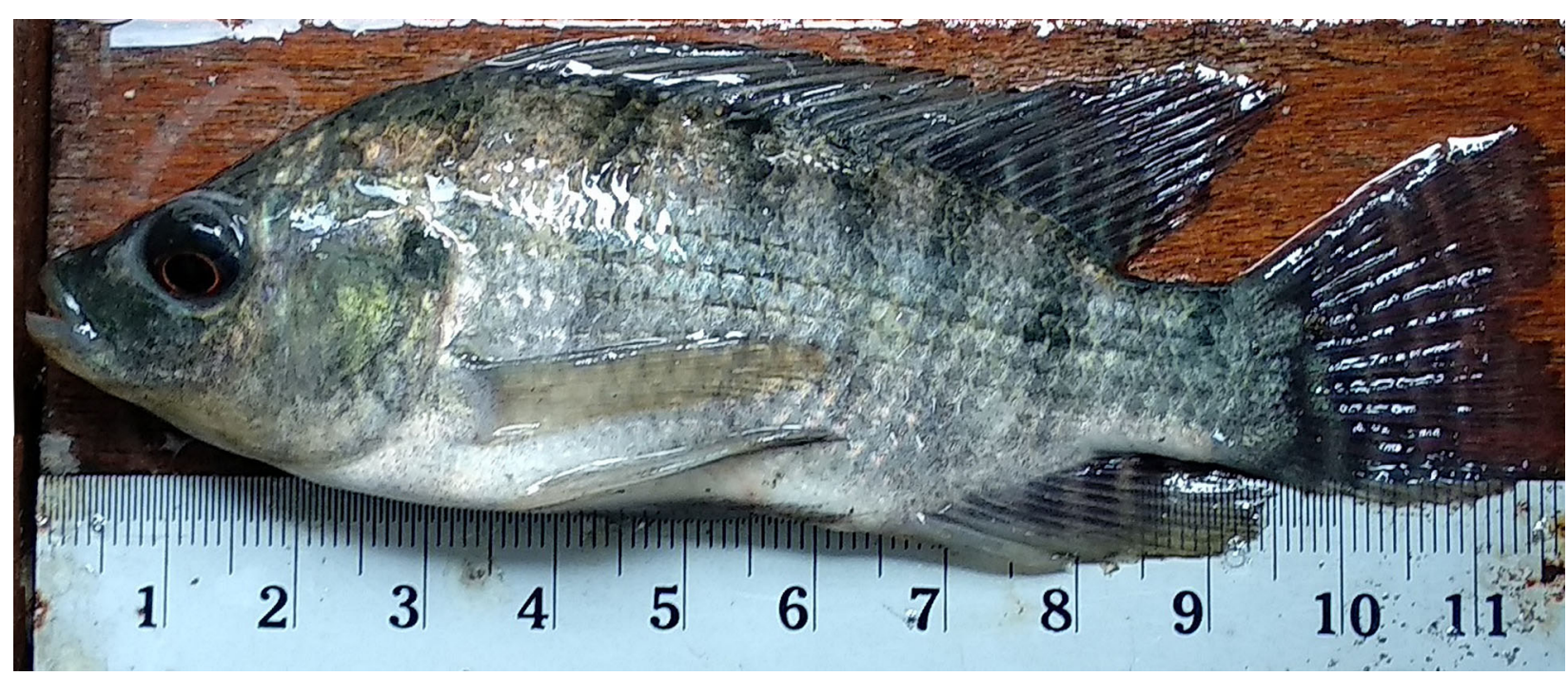

Figure 3. Oreochromis niloticus, Danau Kastoba on Bawean (photograph by V. Hasan).

ranges. Enviromental Biology of Fishes 96 (5): 603-616. https:// doi.org/10.1007/s10641-012-0050-1

Kulac B, Gülüzur A, Mustafa C (2012) Investigations on the ATPase activities and cadmium uptake in freshwater fish Oreochromis niloticus following exposures to cadmium in increased salinity. Turkish Journal of Fisheries and Aquatic Sciences 12: 861-869.

Picker MD, Griffiths CL (2011) Alien and Invasive Animals a South African Perspective. Randomhouse/Struik, Cape Town, 240 pp.

Qiang, J, Yang H, He J, Wang H, Zhu ZX, Xu P (2014) Comparative study of the effects of two high-carbohydrate diets on growth and hepatic carbohydrate metabolic enzyme responses in juvenile
GIFT tilapia (Oreochromis niloticus). Turkish Journal of Fisheries and Aquatic Sciences 14: 515-525. https://doi.org/10.4194/13032712-v14_2_23

Speziale K, Lambertucci S, Carrete M, Tella J (2012) Dealing with non-native species: what makes the difference in South America? Biological Invasions 14 (8): 1609-1621. https://doi.org/10.1007/ s10530-011-0162-0

Tortonese E (1986) Tetraodontidae. In: Whitehead PJP, Bauchot ML, Hureau JC, Nielsen J, Tortonese E (Eds) Fishes of the Northeastern Atlantic and the Mediterranean. Volume 3. UNESCO, Paris, 1341-1347. 